\title{
The Evolution of Post-Postmodernism: Aesthetics of Reality and Trust in Jonathan Franzen's The Corrections and Freedom
}

\author{
Mashael H. Aljadaani \\ Department of European Languages \& Literature \\ College of Arts and Humanities, King Abdulaziz University \\ Jeddah, Dahban, Kingdom of Saudi Arabia \\ Corresponding Author: mhjadaani@uqu.edu.sa \\ Laila M. Al-Sharqi \\ Department of European Languages \& Literature \\ College of Arts and Humanities, King Abdulaziz University \\ Jeddah, Dahban, Kingdom of Saudi Arabia
}

Received: $12 / 26 / 2020$

Accepted: 1/18/2021

Published: $2 / 24 / 2021$

\begin{abstract}
This study aims to find out how literature moves from the postmodern thought, flourished until the 1990s, to the post-postmodern phenomenon. The study traces the evolution of this new phase as depicted in Jonathan Franzen's The Corrections (2001) and Freedom (2010). It proposes these two works as examples of how over the past two decades, literature shifted from postmodernist fiction's irony and skepticism that presents novels as "literature of emergency" to ethical objectivism and neo-realism (Franzen, 2002, p. 258). The purpose of the study is twofold. Firstly, it examines Franzen's deployment of elements such as the subjective perception of truth, selfrestraint, control, and knowledge, which he utilizes to understand reality. Secondly, it explores his employment of narrative tools (e.g., omniscient narrator, metafiction, intertextual dialogue) against postmodern fragmentation and deconstruction. By doing so, Franzen, this study demonstrates, reflects post-postmodernism's core realist ideas that stress pragmatic interactions with the characters and readers' cognizance of reality and encourage engagement with the narrative's language to rework the novel's social and cultural authority. These post-postmodern narratives reference fictional texts, real-life people, and authentic historical events that exemplify various models, simulations, and patterns of reality within and beyond the text, creating a mediated experience that enables communication with and understanding reality.

Keywords: Freedom, Jonathan Franzen, metafiction, realistic fiction, subjectivity, The Corrections, trust aesthetics, post-postmodernism.
\end{abstract}

Cite as: Aljadaani, M. H., \& Al-Sharqi, L. M. (2021). The Evolution of Post-Postmodernism: Aesthetics of Reality and Trust in Jonathan Franzen's The Corrections and Freedom. Arab World English Journal for Translation \& Literary Studies 5 (1).296-323 .

DOI: http://dx.doi.org/10.24093/awejtls/vol5no1.21

Arab World English Journal for Translation \& Literary Studies 


\section{Introduction}

Between the 1960s and 1990s, many critical theories have described how the postmodern phenomenon influenced fiction's subject and structure. Jean Baudrillard's theory of Simulacra and Simulation (1994), about the loss of the "real" and emergence of the "hyper-real" (p.1) shaped the writings of many authors such as Paul Auster and Vladimir Nabokov attempted to represent aspects notions of the postmodern simulacra (i.e., copies that reflect something without an original version). These authors wanted to stress the disappearance of the real and colonization of reality's simulacrum by presenting a non-referential characterization of individual identity. Another critical theory adopted by postmodern writers uses Derrida's Discourse of Deconstruction (2007), which argues how "free play" in a text's language deconstructs narrative structure (p.1). Another example is Donald Barthelme, a novelist, affected by the postmodern thought, and whose fictional writings, such as Snow White, show the death of language as a form of representation. In his fiction, Barthelme plays with the narrative's language to present the novel structure as a "rupture" [series of substitutions], which refers to Derrida's phrasing. The Postmodern thought questioned the central meaning of literary works, especially regarding their authority and knowledge. As a result, the reader must believe that the production of an authorial narrative or coherent subject in literature is uncertain and fragmentary.

Since the 1990s, however, new literary practices have undertaken a rigorous engagement with postmodern literary and social theory to understand its rapidly changing aspects. This engagement resulted in an emergence of writing modes that interrogated the values and theoretical perspectives of the postmodernist writing tradition. Indeed writers of this period, such as Franzen, David Foster Wallace, and Richard Powers, began to be critical of the postmodern forms of literary representation, which they believed, were insufficient to acknowledge the current literary and cultural conditions. Feeling the urgency to surpass/suspend irony and to celebrate sincerity and realism, these writers searched for new styles that celebrate truths, differences, and contradictions through the presentation of real-life people, authentic historical events, and mediated experiences that facilitate communication and contributes to the understanding of reality.

The term "post-postmodernism" describes a literary movement in American fiction in the late 1980 s as a reaction to the growing discontent with values such as plurality, relativism, skepticism, and irony, as characteristics of postmodern literature. Instead, post-postmodernism expressed an interest in aesthetic and ethical values that enables them to engage and connect with the world around them. (Hartness, 2009). According to Smith (2005), "post-postmodernism" seeks to redress postmodern political influences regarding fiction's representation of truth, rationality, or authority, which have been "threatened" by creating variant multiplicity in perceptions and evolutions. Meanwhile, Nealon (2012) defines "post-postmodernism" as a phenomenon that marks "an intensification and mutation" within postmodernism's system (p. x) that is best understood as a as a "toolkit" for the "hermeneutics of [the postmodern] situation" since it is less like a continuous condition of the postmodern "hermeneutics of suspension" (Nealon, 2012, p. xii). While postmodern writers use theoretical tools of hybridity, contradiction, and fragmentation to develop new humanities in the period's social, cultural, and political productions (Nealon, 2012), post-postmodernist writers sought new representations of truth and reality that exist beyond the 
text (Burn, p. 21) through their discussions of topics on environmental future, social media, and ecological problems.

Although post-postmodernist discourse is not based on a theoretical framework, many contemporary writers (e.g., Richard Powers, David Foster Wallace, Zadie Smith, Michael Chapon, William Vollmann, Dave Eggers, Nicole Krauss, and Jonathan Safran) commented on the end of postmodernism, and the emergence of post-postmodernism in their attempt to provide a definition for this emerging trend. Wallace, for example, states that postmodern structures and the invention of irony in literature have reached their limit:

Postmodern irony and cynicism becomes an end in itself, a measure of hip sophistication and literary savvy. Few artists dare to try to talk about ways of working toward redeeming what's wrong because they'll look sentimental and naive to all the weary ironists. Irony's gone from liberating to enslaving. There's some great essay somewhere that has a line about irony being the song of the prisoner who's come to love his cage (Wallace, 2012, p. 49).

On this debate, Timmer (2010) explains that the post-postmodern narrative mixes "high and low discourses on subjectivity" when analyzing an individual's psychology (p. 360). He lists "sameness," "inclusiveness," and "willingness to believe" as primary concepts that reflect the postpostmodern self in its desire to heal from the angst and rage of postmodernism. Post-postmodernist authors move beyond postmodern irony to develop the potential of "language/textual determinism" (p. 360). Some postmodern techniques, such as metafictional devices, are reframed in postpostmodern narratives as realistic elements that reveal a narrative's "realer, more sentimental parts" (p. 360).

Post-postmodern writers lengthily integrate authentic events and relevant issues into their narratives to engage the reader by combining fact and fiction (Yousef, 2017). Febleron explains that modern authors are interested in familial relations and cultural conflicts to illustrate identity issues, demonstrating a growing reemergence of authenticity in literature (cited. in Yousef, 2017). The inclusion of these themes in post-postmodernist narrative expands the dimensions of humankind's various particularities, including various social and cultural structures. So, the postpostmodernist narrative is a literary revolution that centers on realism and its representations.

Franzen is a prominent figure in contemporary literary discourse, and he has advanced the post-postmodernist approach through his writings. Even though his first two novels, The TwentySeven City (1988) and Strong Motion (1992), share some components of postmodern style and content, his subsequent novels, The Corrections (2001) and Freedom (2010), represents a move toward the techniques of a post-postmodern realist approach. These latest novels exemplify Franzen's efforts to connect the new human condition with the existing set of politics to create a sense of engagement and wholeness in the narrative, which may allow for constructive change beyond postmodernism. Franzen demonstrates a commitment to aspects of the post-postmodern trend through his philosophical notions of identity and selfhood, his elaborate discussions on the 
social, economic, technical, and ecological patterns of modern culture, and his revival of stylistic omniscience and metafictional discourse.

This study aims to identify elements of post-postmodernist fiction based on the aesthetics of trust and reality. By analyzing Franzen's works, The Corrections, and Freedom, this study hypothesizes that his works call for a return to a more humanistic writing by depicting orderly worlds and real-life characters. Franzen's post-postmodern character is assumed to have a distinctive identity (i.e., a real-life subject with a consciousness that expresses perceptions and seeks a meaningful existence). This study also seeks to identify Franzen's attempts in the postpostmodern movement to legitimatize the individual's personal experiences working toward identity stabilization. Furthermore, this study hypothesizes that post-postmodern fiction follows an increasing realist style by using the omniscient narrator to provide a broad perspective of the era's socio-cultural politics with extensive insight. The study demonstrates that aspects of metafiction in post-postmodern works are integral to drawing connections between the narrator, reader, and reality, and to representing the post-postmodern tendency to accept differences, and to bridge the gap between the text and reality. This study will also reveal how current fiction, exemplified in Franzen's The Corrections and Freedom, shifts from the postmodern complex narrative patterns employing pastiche, and irony, to celebrate a new version of realism that Franzen identifies as tragic realism.

This study is unique because it explores the specific details found in Franzen's novels in order to trace the changes occurred in fiction since the postmodern time. The paper therefore adds to the literature exist a clear structure of the post-postmodern novel, its various patterns of reality, and its aesthetic views of the subjective truths through Franzen's conception of characters and methods of narration.

\section{Literature Review}

Many critics studied interpreted Franzen's works in the context of post-postmodernism. Tracing the revival of realist tendencies in his fiction in terms of form, characterization, and thematic concerns, these critics argued that like many present-day fiction, Franzen's novels can no longer be adequately described as postmodern. Burn (2008) considers The Corrections to "simultaneously invokes and undermines millennial longing, so it simultaneously rejects and accepts the legacy of the postmodern novel". He argues Franzen's return to realistic techniques by depicting a well-recognized world and ordinary characters, and use of metafictional and intertextual devices, as markers of post-postmodernism. Dawson (2013) also explored Franzen's post-postmodernist tendencies in a study investigating his use of the omniscient narrative technique. Dawson's study classifies the new modes of omniscient narration and suggests that they do not show a nostalgic revival for traditional fiction or parodic critiques of classic omniscience. Instead, Dawson argues that contemporary modes of narration resulted from experimentations with narrative voices at the end of postmodernism. Dawson states that the omniscient narrator in postpostmodern fiction manifests the narrator's knowledge, which is necessary for analyzing the era's culture and represents them as a "public intellectual" (p. 150). Consequently, Dawson suggests that Franzen's work, The Corrections, is an example of a post-postmodernist writer's utilization of omniscient narration to reassert fiction's authority in modern culture.

Arab World English Journal for Translation \& Literary Studies 
Gram (2014) also examines literary realism as a post-postmodern characteristic in Franzen's novels. Gram argues that Franzen's approach in Freedom goes beyond traditional literary realism. Although the novel's representation of global capitalism, environmental degradation, and technological crises, Gram maintains, is akin to "Lukácsian realism," in its use of "theses of scraps of reality with which they have no organic connection" (Lukács, as cited in Gram, 2014, pp. 296; 303), its critique of "growth capitalism" and its potential effects problematizes the novel's realist approach because the demographical and ecological problems presented are "invisible" issues (pp. 311-12).

Annesley (2006) explains that Freedom connects private and public politics with individual and social psychology to reflect contemporary themes. According to him, these themes include strong ties between changes in the individual's realities and globalization, manifested in the novel's pattern and the global economy, consumerist culture, and technologized world. Annesley's study demonstrates how Franzen reveals the realities of personal and social experiences heavily influenced and controlled by globalized consumer culture. Annesley explains that Franzen's primary issue in making The Corrections a "social novel" involves having a level of "cultural authority" that presents globalization as a hegemonic power that shapes his characters' thoughts and attitudes. Instead, Franzen only provides a satirical comment concerning globalization rather than critical insight. ${ }^{2}$ Annesley suggests the novel's "cultural authority" is probable when considering that Franzen's characters take corrective actions regarding the capitalist system (p. 127).

Dubey (2011) also studies Franzen's focus on reality as a post-postmodern approach and assumes that post-postmodernists" "stronger drive toward referentiality" is marked by representing a critique of the social world (p. 365). He explains that current American novelists consider using language that communicates ideas and facts about an individual's reality, aiming to revalue the social novel. Despite this attempt, Dubey argues that post-postmodernist authors (especially Franzen) could not instigate the realist social novel. Since Franzen's account of "tragic realism," as a complex representation of culture, affects his use of referential language, Dubey suggests that this may connect his fiction to the social sphere, a challenge that post-postmodern authors face in mapping the social novel's content and new form beyond the framework of postmodernism.

Hosseini, Pirnajmuddin, and Abbasi (2018) discuss Franzen's The Corrections from a postpostmodernist perspective. They argue that Franzen's novel depicts a constructive rather than a deconstructive approach to reality by showing how Franzen's new version of realism by conflating elements of "contemporaneity with naturalism's determinism" to regain the reader's trust. By highlighting aspects of "ethics, cognition and social minds", the researchers argue that Franzen's use of what he terms "tragic realism" enables him to revive faith in ethical and humanistic responsibility.

Concerning Franzen's delineation of characters in The Corrections and Freedom, Tanenhaus (2010) demonstrates that he reveals several pathways toward "personal liberties," publicly proving that American liberalism's essential paradox is not created by American doctrines but is permanent due to Americans' daily fabricated assumptions. Tanenhaus explains that Franzen illustrates his concept of a new, appropriate form of individual, personal freedom by focusing on 
family life. When the socio-cultural atmosphere is engulfed by the growing American economy, he establishes "corrections" for depressing obligations and highlights that Franzen's attempts to focus on real humanism subjects - at the social and individual levels - break postmodernism's cycle (Tanenhaus, 2010).

Solomon (2001) highlights this realist identity and discusses subjectivity as a vital element for destabilizing the postmodern skeptical view. Solomon explains that the "break" with skepticism marks a "return to subjectivity" (p. 87), focusing on the individual's personal feelings, aims, and attitudes toward his world. Solomon demonstrates that the shifting canon from a universal system to the individual level translates the philosophy of the "real or authentic existence" (p. 85) to a human, a theory that post-postmodernist writers currently aim to revive.

While these studies explore specific aspects of Franzen's post-postmodern fiction, this study aims to provide an in-depth critical assessment of this phenomenon by analyzing The Corrections and Freedom. Primarily, this paper explores the ways in which the post-postmodernist approach moves beyond the uncertain, postmodern perception of fact-based knowledge towards the aesthetics of reality and trust in fiction. First, the study explores the various levels of subjectivity manifested in Franzen's characters regarding the concept of truth in literature, which demonstrates the individuals' "mutual respect of difference" in perceptions or ideologies (Rudrum, as cited in BOYNE'S, 2017). Thus, having various subjective truths is illustrated as a motive for strengthening the characters' consciousness about reality. Second, the study analyzes Franzen's use of specific narrative techniques, such as omniscient narration, intertextuality, and metafiction as narrative elements that enforce the aesthetics of reality and trust.

\section{Discussion \\ Subjectivity and Truth}

The aesthetics of reality and trust in literature require that characters be presented with a coherent identity that is not influenced by institutional powers, such as a culture or society. This approach involves handling various levels of subjectivity that provide justifiable reasons for the characters' thoughts or behaviors through self-understanding (Van Katwyk, 2009). In The Corrections and Freedom, Franzen explores various levels of characters' perceptions of truth; some create a story of authentic existence by extending dimensions of selfhood and self-knowing, which reveals that subjectivity is an essential component of the character's consciousness of reality. Other characters maintain a lesser degree of subjectivity, as they are socially or culturally influenced, causing them to misdirect their life choices and become subservient to these powers. A culture's political practices or any institutional capacity in the narratives seem unjustifiable compared to the individual's consequent behaviors, attitudes, or ideologies. Franzen's discourse attributes a character's failures to creating a coherent self-identification that relates to the nature of their society and culture. His discourses are "modes of representation" that "endow the individual subject." 4 They help humans develop a cognitive appreciation of their position in the world (Jameson, as cited in Hidalgo, 2017).

To justify their actions and empower their coherent identity, Franzen explores the relationship between individuals and their political systems: "if I could capture the way larger 
systems work, readers would understand their place in those systems better and make better political decisions" (Franzen, as cited in Hidalgo, 2017, p. 106). In Franzen's works, characters fail to embrace any level of subjectivity. They are either overwhelmed by social demands that diminish their sense of personal freedom, or are weighed down by the rules of social conformity, which influences their life decisions. This low level of subjectivity illustrates why postpostmodernists stress subjective self-recognition in their shifting world, as this kind of personal appreciation helps one regain the capacity to act and struggle.

Franzen's depiction of a post-postmodern character reflects a tendency towards a coherent self, which modulates the postmodernists' deconstruction of characterization. Franzen argues that "[p]ostmodern fiction wasn't supposed to be about sympathetic characters. Characters, properly speaking, weren't even supposed to exist. Characters were feeble, suspect constructs" (Franzen, 2002, p. 6). This means that a character's consciousness overlaps with the plot's complex, incoherent layers. Since postmodern characters lost their sense of identity, they experience a state of unknowing, ambiguity, and indeterminacy; their actions and thoughts seem unpredictable, even to themselves. These characters create an illusionary world to hide their fragmented psychology and alienate their identities from a contradictory world that they cannot harmonize with, becoming more "familiar with the void" (Hassan, Rudrum \& Stavris, 2015, p. 211).

Contemporary authors primarily avoid the postmodern mode of characterization because they want to explore profound, authentic representations of emotion and experience, as they were informed by the postmodern critique of the 'naïve' belief that language can be a true mirror of reality" (Burn, p. 20). Like Franzen, contemporary writers aspire to "simultaneously invoke and undermine millennial longing by both accepting and rejecting the legacy of the postmodern novel (Burn, 2008). They were concerned with reviving realistic social novels because the period of postmodern narratives has ended, but they were preoccupied with theoretical explanations of nonreferential language uses and dissociations from reality (Dubey, 2011). These deconstructive narratives were designed to cope with the aftermath of World War II and the cultural forces of Capitalism and Marxism. Although these theoretical representations successfully conveyed the fragmentary spirit of that period, the world is currently experiencing various crises. Brown (2012) emphasizes the importance of configuring the critical theories that a person inherits and stresses the dangerous effect of following postmodern theories of deconstruction. This danger lies in the individual's mistaken belief in the collapse of everything valuable, including humans and their humanness. Thus, Brown emphasizes the need for radical responses to the era's theoretical contexts and people's genuine experiences. Otherwise, these theories will be denied.

The post-postmodernist narrative rejects postmodern notions of the fragmented character that lacks self-knowledge or self-control and embraces selfhood and subjectivity. With regards to subjectivity and its conceptualization of the individual's consciousness in contemporary works, modern-day authors explicitly express emotions and opinions in enhancing existence and unity, as opposed to the postmodern era's fragmented absence (Timmer, as cited in Hendry \& Page, 2013). Post-postmodern fiction's engagement with meaning, and presence can be attributed to the desire to develop meaningful presence, connectedness, and communication (Hendry \& Page, 2013). This desire is anchored in common intersubjective perceptions of "emotions and experience", (Hendry 
\& Page, 2013, pp. 56-57). Therefore, late postmodern fiction expands subjectivity to its highest level by placing "Man" and his consciousness as the "subject of art" (Hassan, Rudrum \& Stavris, 2017, p. 287).

Subjectivity refers to a person's realization of how they must create a coherent personality. In this psychological situation, a person becomes conscious about their identity (e.g., inner thoughts, characteristics, and ideologies), including what constitutes them and where they come from (Hall, 2004). According to the theory of knowledge and existence, subjectivity (with reference to the intersection between epistemological and ontological philosophical questions) demonstrates how "our understanding of knowledge [may] relate to, impact, and/or constrain our understanding of our own existence" (Hall, 2004, p. 4). Finkelstein (2007), however, analyzes the effects of high socio-cultural agencies on the individual to define subjectivity as the "condition between the inner and the outer in which thoughts and sentiments are parts of a political, economic, and historical flow of ideas" (p. 174).

In Franzen's The Corrections and Freedom, the characters' personal accounts are shaped on many levels to create multiple ways of being and different levels of subjectivity. The Corrections is "a theatre Franzen has designed to bring the different conceptions of selfhood his characters draft to explain themselves to themselves into conflict" (Burn, 2008, p. 115). Some characters have a coherent awareness of their subjectivity, providing observations and analyses of their actions, behaviors, thoughts, and ideologies to translate their experiences and understanding of the world. With this reliability, the characters cannot falsify or fabricate their experiences or views, even though they may contradict social or cultural doctrines. Other characters, however, cannot identify themselves within the scope of subjective identity. Franzen's exploration of different personal accounts makes truth "so variable for each of us, that other people have difficulty in recognizing what it is" (Proust, as cited in Burn, 2008, p. 125). In a post-postmodern situation, social affirmations of an individual's subjective history, actions and thoughts is unimportant. What matters, however, is these individuals' mutual respect for one another's personal ideologies. For mutual respect open possibilities for mutual understanding of motivations and choices (Burn, 2008, p. 24).

Franzen primarily depicts various levels of subjectivity to offer redemptive narratives and advocate for fiction's role as a tool for social reform. Franzen provides several "salvational narratives" (Hidalga, 2017, p. 3), which serve as self-legitimatizing policies and ideologies. In other words, Franzen achieves personal and literary redemption through these salvational narratives. In his social novels of the twenty-first century, some of his fictional protagonists (like himself) are psychologically secure when they accept ethical commitments while rejecting the twentieth century's sociopolitical practice of self-interest. Franzen emphasizes redemptive plots (e.g., reconciliation and self-development) as the keys for securing the individual from personal and social contradictions:

Writing is a form of personal freedom. It frees us from the mass identity we see in the making all around us. In the end, the writer will write not to be outlaw heroes of some 
under culture but mainly save themselves, to survive as individuals. (Delillo, as cited in Hidagla, 2017, p. 4)

In the late twentieth century, the relationship between subjectivity and truth became essential subjects for debate. Foucault (1997) explores this relation not only by examining the effects of subjectivity on the individual's conception of truth, but by tracing historical accounts of social politics and personal ideologies to define various ethics, techniques, and practices that form what her terms the "hermeneutic of the self" (p. 93). Foucault argues that the demand for a focus on the interiority of a subject in contemporary art is increasingly shifting from the "art of governing" (represented in three movements: "government, population, and political population") towards the "art of living," which emphasizes "self-understanding, "subjectivity," modes of existence, and ways of being (cited in Lynch, 2012, pp. 160-198). To overcome problematic self-knowledge and identity issues, Foucault explains that creating new modes of expression through philosophy strengthens one's sense of being, and broaden his/her choices in life: "what is philosophy after all? [I] f not a means of reflecting on not so much on what is true or false but on our relation to truth? How, given that relation to truth, should we act?" (p. xx).

Chirs Abani: Global Igbo (2015) also stresses the importance of presenting characters as humans searching for possibilities of political unity between and within cultures, societies, and relationships to secure personal redemption or survive trauma. Whether it involves the spiritual/secular, seen/unseen, or the metaphorical/material, this political unity is constantly changing and compelling humans to think of the self, identity, and being as thoughts and performances that fluctuate, like "simulacra." For Abani, the "journey of consciousness" is "a composure" that is not based on a specific morality or doctrine but on finding one's distinctive identity. To allow peaceful existence without "violence or shame," a person must work with all these components to create an elaborate metaphor that is ethically accepted when compared to human nature (Chris Abani: Global Igbo, 2015).

Franzen conceptualizes various levels of subjectivity to reflect self-realization processes. The post-postmodern self may feel disconnected from reality but still provides solutions for this problem. Assuming that others share their skepticism, his works consider circumstances of hesitation, dispersal, and doubt. When experiencing the confusion derived from self-realization, these characters hardly change their priorities and values to avoid self-doubt, deception, or skepticism concerning their self-coherent experiences. They may easily conflate their sense of self and the period's spirit by exploring practices that may secure their subjects. In other instances, they surrender to forces beyond their understanding to live in harmony with these powers. This identity-framing is reflected in most of Franzen's characters, who tend to initiate different modalities of selfhood or embrace alternative ideologies to avoid self-deception, self-sacrifice, or self-doubt due to social, cultural, and economic forces.

\section{The Corrections}

The Corrections conceptualizes a mode of subjectivity that manifests possibilities of characters' mental coherence, self-control, and self-knowing. For example, Alfred Lambert, a retired Midwestern father, presents a highly sophisticated level of self-control. At first, Alfred feels 
confused about how to express his personality. Although plagued by the loss of concentration and its "complexity" as he ages, which makes expressing himself a struggle, he retains his strong masculine identity (Franzen, 2001). As a conservative, Alfred was the head of the railroad's Engineering Department, until it was purchased by venture capitalists. He quits his job, sacrificing his pension, and he reflects that America used to belong to "upper-middle-class northern European men," like him - hardworking and practical - but now, they are voiceless and cast out (Franzen, 2001, p. 372). Albert punishes whoever is opposed to his principles, demonstrating self-restraint and responsibility toward his persona.

To face his radical culture, Alfred resorts loneliness as a form of self-empowerment as a reaction to his misperceptions about his worsening health condition. His tendency towards selfisolation grows deeper when he discovers that his chair is not electronic but made of Popsicle sticks: "Maybe a floor became truly a floor only in his mental reconstruction of it" (Franzen, 2001, p. 355). Alfred even becomes more suspicious that every "real" instinct strengthens his consciousness with "righteousness, of uniquely championing the real" that is only abstract (Franzen, 2001, p. 355). Alfred's feeling that the world is "uncaring," makes him prefer isolation from the physical world, including others. It further increases his desire to dissociate himself from his intimate social relations, empowering himself against others' sentimentality, which he believes weakens his self-control. Loneliness becomes his source of self-empowerment rather than social familiarity, even though he admits, "I've suffered from depression all my life" (Franzen, 2001, p. 29). His confession is not a request for empathy but a sign of self-realization. When a character realizes certain aspects of their personality and wants verification from others (even if it is negative), it illustrates Swann's "Self-Verification Theory" (2011). This theory proposes that some seek self-verification because it gives them a sense of coherence and protection (Swann, 2012). This idea is indicated in Franzen's essay collections, How to be Alone (2002). In this book, Franzen suggests that "the most important corrections [of The Corrections] are the sudden impingement of truth or reality on characters who are expending ever-larger sums of energy on self-deception or denial, [which affects] the more soul-like aspects of the self' (p. 80). Alfred's responses to the changing world around him, his depression, and isolation are all corrections that he deliberately makes to prove his self-awareness (i.e., that he is different) to others.

Alfred estranges his aged identity from others to prove that he is aware of his inner personality's uniqueness and does not need affirmations from external sources to assert his coherent subjective self. Kristeva argues that the elderly usually construct an "uncanny" conception of identity that works as a shelter from change, and this "uncanniness" presents the "self"s strangeness" to raise their awareness of being different from others (as cited in Defalco, 2010, p. 12). Old age is a stage to confront "the uncanniness," which already exists within the mind and can present a new understanding of elderly identity (Defalco, 2010, p. 12). This realization allows for the self to be ethically accepted, helping the individual progress beyond self/other contradictions (Defalco, 2010). Alfred's uncanny experience illustrates his restless psyche and provides him with self-appreciation, which elevates his potential to the highest level of moral consciousness (Defalco, 2010). Despite his worsening mental disorder, Alfred familiarizes his abnormal condition by demonstrating his differences, like when he tells Denise that his depression is unrelated to his 
illness: "[h]e was depressed when he was still in perfect health" (Franzen, 2001, p. 278).

Despite his mental depression that worsened with his retirement and aging, Alfred's selfcontrol manifests the post-postmodernists' preoccupation with a coherent identity. In postpostmodern contexts, the representation of the psychological difficulties facing the elderly (e.g., paranoia or other personal struggles) never shows "the inability of the body to adequately represent the inner self" (Defalco, 2010, p. 16), which is a situation that usually occurs in postmodern narratives. Instead, these struggles represent the elderly's capabilities to hold still against the period's socio-cultural changes. Alfred enforces his unique identity against the cultural dynamics of the new world, such as consumer economics and the free market. These forces are presented in contemporary narratives (especially American novels) as a "colony," or an authority that struggles to construct its characteristics based on those who fight to maintain their era's beliefs and practices (Millard, 2007, p. 5). Consequently, Alfred creates his identity based on a different set of values and priorities; he retires when his workplace consists of people he believes are less worthy than him. He favors loneliness when others pity his illness and prefers a dignified death rather than being overwhelmed by social sentiments.

Denise also maintains a high level of subjectivity in the narrative; she is presented as a successful woman who continually cares for the Lambert family. However, she defines her subjectivity as not being "part of anybody's life" (Franzen, 2001, p. 657). Regarding her personal freedom, she fights self-destruction and confusion by determining decisions without feeling distressed or explicitly recognizing social norms. For example, she marries her mentor, Emile Berger, against her parent's will. Based on her desires that violate the typical social structure, she breaks off the marriage, longing for a love triangle between her boss, Brian, and his wife, Robin. Denise also struggles with her freedom and acts against societal standards when she has an affair with Don Armour, her father's colleague, who had just blackmailed him. Although this relationship may ruin her father's reputation and affect her family, she has no reluctance to pursue it, despite Armour's old age — contrasting her teenage years — and married status. She proposes the affair and brings "her perfectionism to bear on a whole new world of skills" (Franzen, 2001, p. 485).

Denise underpins her subjective mode of existing without troubles. She never accepts the impossible while she develops her individuality, as her family does. Instead, she perfects her identity in various areas of her life, from her "sexual voyage" to the "restaurant arena," to avoid the agonies of existence (Weinstein, 2015, p. 129). She realizes that her family is troubled by endlessly attempting to correct their poor choices, so she desires to take opportunities of pleasure when they arise: "By trying to protect herself from her family's hunger, the daughter accomplished just the opposite" (Franzen, 2001, p. 648). Denise wants to hold on to her freedoms to break free from the oppressive feelings of self-denial and self-sacrifice. In this process, she deepens her selfadmiration: "Maybe she wanted to make Robin like her simply to deny her the satisfaction of disliking her- to win that contest of esteem. Maybe she was just picking up the gauntlet. But the desire to be liked was real" (Franzen, 2001, p. 517). Feeling "sick of watching [her]self be cruel to [him], a state that can destroy her life's model of self-control" (Franzen, 2001, p. 657), Denise, finally, breaks off her relationship with Robin, longing for personal freedom (rather than feeling obligated by societal norms).

Arab World English Journal for Translation \& Literary Studies 
Denise manifests a high level of self-knowing, revealing an elevation of the postpostmodern subjective character of conscious experience; she does not question her identity or opinions but criticizes others' failure to appreciate her. Burn (2008) explains that Denise is "sufficiently self-conscious to detect different drafts of her identity" (p. 132). She filters her narrative perspective toward pleasure and provides explanations for her identity, like when she is fired from her job, "she told herself a story" to "recognize herself" to explain her behaviors rather than become overwhelmed by failure (Franzen, 2001, pp. 648-49). She interprets her experience solely from her perspective, which does not include others' opinions. After breaking off her relationships, she does not justify her actions. For example, when her friend, Julia, asks if she had met anyone, she replies: "I'm seeing nobody" because she "didn't want to hear her voice go small and soft with sympathy" (Franzen, 2001, p. 651). Therefore, she constructs her subjective reality without contradictions or confusion.

Other characters in the novel, like Chip and Gary, have lower levels of subjectivity to reveal their challenges facing the post-postmodern identity while trying to construct personal and subjective perceptions of reality. In the beginning, they cannot maintain coherent subjective perceptions of their actions and ideologies. Still, eventually, their unstable subjectivity is revealed as an effect of an imbalance between their inner feelings/thoughts and social constructs. Their mistaken beliefs and attitudes correspond to more extraordinary, external powers (i.e., sociocultural values). For example, Gary is a "strict materialist," who treats his father like "some wornout old machine" and betrays his mother. Still, these misbehaviors are revealed to be destructive patterns that have resulted from the free-market, which is also responsible for his intense paranoia and depression. Similarly, Chip's flawed behaviors are associated with his psychological "health" problems and involvement in "the consumer economy" (Franzen, 2001, p. 44). Since these characters cannot balance their minds with social and cultural authorities, they cannot construct their subjective principles or attain subjectivity. Their struggles against these forces embody the post-postmodernists' interest in the self-confident, secure personality with faith in their ideologies over public politics.

Chip's life complexities are framed by social and cultural influences that the author presents as hindrances to form his subjectivity. Chip is a college professor struggling to prove his identity at the personal and social levels. Since he is unable to develop a satisfactory perspective of socio-cultural conformity, he demonstrates immaturity. He believes that he "had almost nothing to persuade himself that he was a functioning male adult, no accomplishments to compare with those of his brother" (Franzen, 2001, p. 28). As he teaches the introductory theory course, "Consuming Narratives," Chip must construct various assumptions and theories concerning social matters, which do not only influence others' views of him but also his self-recognition (Franzen, 2001, p. 49). Chip's student, Melissa, declares in class that he sketches fragmentary narratives of modern cultural studies to construct lies that enhance "the state of criticism" (p. 60). She states that while the society lives in a situation where "[n]obody can ever quite say what's wrong exactly", Chip tries to make effective judgments on his society and culture: "It is so typical and perfect that you hate these ads!" (p. 61). Melissa thinks that Chip criticizes cultural values (e.g., consumer capitalism) as "sick," even if they are functional in society because it is "useful work" for him (pp. 61-62). It is paradoxical because although Chip is engaged in the problems of critique 
and judgment, he, no longer able of recognizing his abilities and standards, cannot complete his film script, The Academy Purple, as he feels "powerless to keep the bitterness of his voice" (p. 60). Even when he celebrates its partial completion, he remains dissatisfied (p. 121).

Chip's immature actions are not motivated by instincts. They are the products of social and cultural influence. Franzen manifests significant sympathy towards the young professor by making him "a victim of the social power of women and minorities" (Toal, as cited in Hidalgo, 2017, p.159). To overcome these powers, Franzen makes Chip commit social and moral violations (e.g., taking drugs and stealing money), causing him to be expelled from the university and to take a job in Lithuania, running a fraudulent investment scheme. This corruption scheme influences Chip, who states that his identity is deluged by the power of these institutions: "I personally am losing the battle with a commercialized, medicalized, totalitarian modernity right this instant" (Franzen, 2001, p. 44). When Lithuania's government collapses, Chip transforms into a responsible person with the "emotional maturity" (p. 106) that he recognizes in his sister. He begins to value his moral duties towards his parents and feels guilty over past carelessness: "I could understand being responsible for them. Parents have an overwhelming Darwinian hard-wired genetic stake in their children's welfare. But children, it seems to me, have no corresponding dept to their parents" (p. 563). After defeating socio-political influences, he reframed his life story, which was the novel's most complete resolution; as Enid observes, "Chip, in particular, seemed almost miraculously transformed" (p. 728).

Gary's identity is also conditioned by cultural constructs, including Western forces of fierce individualism and materialism, which create an inner struggle. Throughout the narrative, his identity shifts between being responsible and negligent and depressed and mentally stable. On the one hand, Gary's materialism and individualism are evident in his response to his father's retirement from the Midland Pacific Railroad when he suggests selling his parent's house: "The first order of business, as Gary saw it, was to sell the house. Get top dollar out of it, move his parents into someplace smaller, newer, safer, cheaper, and invest the difference aggressively" (Franzen, 2001, p. 226). Moreover, he has several financial arguments with Enid, where he demands that she repay him $\$ 4.96$ for six bolts, even while he earns thousands of dollars in investment. Gary's market-oriented behaviors become part of his mental orientation: "although in general Gary applauded the modern trend towards individual self-management of retirement funds and long-distance calling plans and private-schooling options, he was less than thrilled to be given responsibility for his own personal chemistry" (p. 181). He believes that his "strict materialist" actions can give him a position of power as an active, responsible member of the family (p. 184).

Gary assumes the role of an economically minded individual, affirming his authority and power because he wants to persuade others that he is not "clinically depressed," regardless of his symptoms (Franzen, 2001, p. 210). He fears to admit his problem and suspects that if he does, he will lose his right to have opinions: "He would forfeit his moral certainties; every word he speaks become[s] a symptom of the disease; he would never again win an argument" (p. 210). To continue disguising himself as a wise man, he attempts to enhance his mother's expectations of him by adopting her "illusions" of life in the sixties (p. 342).

Arab World English Journal for Translation \& Literary Studies 
On the other hand, Gary will shift to his natural identity when he needs social sentiment. When Caroline thinks Gary is "changing the rules on her," he states, "that the nature of family life itself was changing" rather than his persona (Franzen, 2001, p. 215). So, Gary relates his changing condition to the "nature" of his cultural life and not only to his mental disease, confessing that these cultural shifts are beyond his control. To comfort himself from his anxiety, he seeks protection under his wife's psychological domination. Her constant remarks on his actions and feelings make him feel better: "he'd collected certain remarks of her into a kind of personal Decalogue, an All-Time Caroline Ten to which he privately referred for strength and substance" (p. 240). Gary is not only paranoid and irresponsible but "he was less than thrilled to be given responsibility for his own personal brain chemistry" (p. 182).

The representation of Gary's struggles between personal will and cultural influences emphasizes culture's role in obliterating self-awareness. Franzen describes how culture creates binary identities:

We live in a reductively binary culture: you're either healthy, or you're sick; you either function or you don't. And if that flattening of the field of possibilities is precisely what's depressing you, you're inclined to resist participating in the flattening by calling yourself depressed. (Franzen, 2002a, pp. 316-17)

Both sides of Gary's character reflect processes of fabricating his identity, as he searches for explanations to justify his behaviors and live in harmony with a challenging culture. These hesitations are crucial in proving that "the great Materialistic Order of technology and consumer appetite and medical science really was improving the lives of the formerly oppressed" (Franzen, 2001, p. 61).

A third type of characterization in Franzen's The Corrections proves that if a person does not construct their subjective perspective and way of life, they will not find a good sense of being. This is represented by Enid, the Lambert's family's loving yet demanding, mother. Enid constantly demands her children's sentiment and desperately requests them to join her in "one last Christmas in ST. Jude" (Franzen, 2001, p. 101). She longs to build an image of a well-connected family, which contrasts with their reality. According to Gary, "Enid's obsession with Christmas" is "a symptom of a larger malaise, a painful emptiness in Enid's life" (pp. 192-93). Due to her sense of worthlessness, Enid pursues a plan for self-transformation that satisfies others, which misrepresents herself for the sake of social acceptance.

Enid's constant self-deception is the only way to define her social identity as a wife or mother. She relinquishes her rigid identity to accept things that violate her standards to ensure that others feel her overwhelming compassion. For instance, she accepts her daughter's homosexuality because she does not want to be critical and stand in the way of her daughter's "happy and settled" life (Franzen, 2001, pp. 665-66). However, when she is not critical of acts that violate her ideologies, Enid feels ashamed and takes a medication called "Aslan" to cure her "chemistry of shame" (p. 412). Although she describes how her family causes her emotional trouble, she cannot resist others' commitments. Alfred observes that Enid represents a 
"[w]oman [who] pays the debt of life not by what she does, but by what she suffers; by the pains of childbearing and care for the child, and by submission to her husband, to whom she should be a patient and cheering companion" (p. 344). Her devotion in helping everyone but herself makes these social relations the "governing force[s]" that trouble her life. (p. 12)

\section{Freedom}

Franzen's illustration of his characters' subjective desire to come to terms with reality is further explored in Freedom, which dramatizes the role of subjective truth as a post-postmodernist technique to represent reality in fiction. In this novel, the characters' subjectivity is associated with their desire to be liberated from demanding social obligations. Walter, for example, acts as an autonomous, independent identity who achieves a high level of subjectivity by managing to escape others' influence. He utilizes his unique potential to accomplish certain goals, such as his environmental project. In this sense, Walter maintains a level of self-knowledge that empowers his coherent, stable existence. However, a character may fail in attaining a coherent subjectivity when they cannot detach their personality from others. Patty, the female protagonist, represents this characterization because she constantly seeks others' agreeability. Her subjectivity appears as troubled throughout the novel, except in the chapters that are narrated as an autobiography of her reality. In these parts, Patty is redeemed by personal liberation. The memoir allows her to either compromise her failure, or reevaluate her success, and develop a level of subjective selfidentification.

Walter's identity develops from being a self-sacrificing member of the family to a selfinterested individual. First, he relinquishes his desire to be an artist to pursue a career that consumes his free time to elevate his parents' financial situation and meet his wife's expenses. His voice is silenced, as he bears the pressure of his family's mistakes: "Walter is a portrait in the displacement of unspeakable rage about what's going on in his family through speakable rage about what's going on in his country" (“Jonathan Franzen Takes," 2010, para.1)

Walter builds his subjective identity by demonstrating personal power and confidence through self-discipline. During his interpersonal development, Walter insists on avoiding destructive habits. He believes that personal freedom causes the world's troubles and is convinced that any "liberal state can self-correct" when "increasing restrictions on its personal freedoms" (Franzen, 2010, p. 138). Therefore, the only policy Walter pursues to confront disagreeable, painful, or embarrassing matters is limiting his freedom. When a person wishes to preserve their "moral subjectivity," they may choose certain reactions in response to many experiences (Koubová, 2013, p. 33). Thus, to have a specific level of subjective moral personality, Walter assumes self-imposed restrictions. For example, Walter shows self-restraint toward his father's abuse by refusing passive action and not complaining about his father's cruel tasks. His restraint "showed his father that he could beat him even at his own game (...) if Walter hadn't been perpetually occupied with hating him, he might have pitied him" (Franzen, 2010, p. 605). He also demonstrates self-discipline when he avoids engaging in family quarrels, like when he prefers not to argue with Patty about her support for their son, Joey, or exert any effort to stabilize his relationship with her. 
Walter's self-limitations enhance his rationality, allowing him to distinguish between right and wrong based on reasoning. For example, his copious research and statistical studies on the relationship between societal and environmental matters is what makes him able to eloquently justify the subversive idea that humanity is "A CANCER ON THE PLANET" (Franzen, 2010, p. 655). His rational thinking is aided by his inner will, a kind of control or authority within his psychological power. According to Koubová (2013), "the self-limitation of the will" motivates a person's rational thinking (p.13), so reason (as a form of thinking that directs self-limitation) fulfills several methodological presumptions. For example, the notion of truth is direct evidence of existence because it presents a clear knowledge of all things. The result of this trust and knowledge creates a "principle of identity," a specific explanation of one's personality "being itself" (p. 9). Walter's self-restriction allows him to develop his rational thinking and inner will to maintain his identity's principle. Instead of putting significant effort into convincing others of his personality's richness, he pursues his dream to enrich his interests and invests his time in a project to establish a campaign against humanity's overpopulation and environmental destruction. His ecological engagement is not an act to retire the society, but it represents a free space to embrace an ethical commitment without indulging in social problems. Thus, the choice of existence is based on his identity's principle, which is evinced in the "Free Space movement" project he initiates to create public, open spaces (Franzen, 2010, p. 492).

Walter's self-management maintains his coherent identity, demonstrating an exceptional level of subjectivity. He does not align his narrative with any form of commitment to others in the social realm but assumes a level of self-discovery without externally imposed restrictions. As he reflects on how birds kill for food: "To me, that's what makes nature peaceful... it's not all poisoned with resentment and neurosis and ideology. It's a relief from my own neurotic anger (...) and I'm not so compromised and I'm not having to deal with people" (Franzen, 2010, p. 663). Walter looks for "refuges" for the birds, but he finds one for himself, where his thoughts and actions can be "founded on accurate self-knowledge" (pp. 669-630). Rabinow (1997) believes that once a man designates a level of self-knowledge from an activity for "the care of the self," he constructs a mode of living (p. 94) Therefore, Walter's self-limited personality at the social level and his pursuit of a personal activity that does not require socializing with others does not show weakness or powerlessness but proves that Walter has chosen a mode of living based on his identity's principles, empowering his subjectivity.

In Freedom, Patty represents the importance of subjectivity to reconcile truth. She is the devoted wife and loving mother of the Berglund family, who comes to this realization too late. She is presented as a burden to others and thinks of people's "compliments" as "a beverage" to assert her social "agreeability" (Franzen, 2010, pp. 70; 50). In her youth, she devotes herself to basketball ("her religion") and sacrifices everything to pursue it because it gives her space to be "the best... brilliant and beautiful," according to others' opinions (p. 114). Patty's "thirst" for complements causes her to continually misjudge her personality. So, if she receives no praise, she cannot progress. Since she would rather see herself as "a person who, by her own admission, made nothing but mistakes" (p. 474), she cannot refrain from constructing her life on the choices others offer. 
Patty's search for agreeability stimulates unhealthy relationships, especially with her husband, Walter, and her college friend, Eliza. Her decision to marry Walter is crucial to change her sisters' and mother's the views about her lack of social credibility after her career-ending knee injury. This obstacle prohibited her from being a famous basketball athlete (Franzen, 2010). After their marriage, Patty is unsatisfied with Walter's acts of civility and protectiveness show to express his desire for her. She even betrays Walter and becomes involved in a relationship with his best friend, Richard Katz. She knows that Walter's impression about her goodness is wrong, but she pretends to love him to continue feeling desired.

Her search for social acceptance is enhanced when she befriends Eliza, who remarks that Patty is the best basketball player on her team and needs "protection" (Franzen, 2010, p. 71). As a result, their unhealthy friendship strengthens although they have nothing in common. Although the psychologically damaged Eliza negatively influences Patty's relationships, Patty still accepts her as long as her personal freedom is retained. While Patty's life predominantly centered around sports, in 'dark little Elizaworld,' she 'didn't have to bother trying to be so good"' (p. 74). Patty fails to recognize that Eliza exploits her need for compassion. For example, Eliza tells Patty that has terminal cancer, although she is merely experiencing a drug's poisonous effects. Patty's fruitless search for social acceptance causes her to reject Eliza: "Patty's entire document attested to the exhausting difficulty of figuring out... what was 'good' and wasn't" (p. 509). Overtaken by Eliza's recognition, Patty cannot "dedicate herself more intensely than ever" (p. 125).

Although the author presents Patty as irresolute, having to make her significant life decisions based on others' agreeability, he offers her the opportunity to negotiate and elevate her subjectivity. In a third-person voice (at the behest of her psychiatric therapist), Patty writes her autobiography, which helps her identify herself as a distinguished subject. As she recounts her mistakes, she recognizes that "temptations of self-pity" make all her choices for social recognition "miserable" (Franzen, 2010, p. 246). Her autobiography provides a space for drawing her identity again and offers her the opportunity of self-reflection. She recognizes the erroneous decisions that lead to her "lowest of low points" (Bamberg, 2011, p. 323). The author gives her a new form of agency to elevate herself to become a new person (p. 323). She understands that she does not need to be agreeable for stability, as this desire is destructive to her self-discipline: "The autobiographer is almost forced to the conclusion that she pitied herself for being so free" (Franzen, 2010, p. 246).

Characterization in Franzen's The Corrections and Freedom reflect the post-postmodernist focus on the importance of subjectivity in finding a stable mode of by adapting the aesthetics of trust and reality. It alters the postmodernist skeptical views concerning the representation of the individual's consciousness about his identity. Since postmodern theories, which mirrored an age of fragmentation and contradiction, no longer fit the individual's thinking in the late twentieth century, Franzen depicts a new identification of the individual who can find harmony in a radically changing world and create genuine connections. His characters demonstrate remarkable variations in their pursuit of subjectivity. Some successfully perceive the post-postmodernist conception of self-consciousness through their performance of various modes of subjectivity, while others struggle to recognize the total subjectivity of their narratives. In The Corrections, Franzen presents Alfred and Denise characters with coherent subjectivity, who are intensly aware of their life's 
ideologies, and whose consciousness flourishes as they legitimize their perceptions against social and cultural forces. For Alfred, self-isolation becomes a source of empowerment and selfrecognition. Likewise, Denise's multiple, non-traditional affairs are means to fight her selfdestructive instincts and sexual confusion and break free from excessive self-denial and selfsacrifice.

\section{Narrative Style}

Contrary to postmodern novels, in which the omniscient narrator is almost absent, The Corrections and Freedom demonstrate how Franzen's employment of the omniscient narrator and metafiction support the novels' realistic approach. This narrative style is strongly associated with the post-postmodernist renewed engagement in social issues. The authenticity and sincerity of the post-postmodern narrative necessitate an authorial narrator to affirm the plot without casting doubt on its subjects" validity that forces the reader to become involved in the subject "without falling back into a distanced mode" (Yousef, 2017, p. 39). The omniscient narrator has been reinstated in post-postmodern fiction with specific criteria. First, this all-knowing, all-seeing perspective on social, cultural, economic, or political conditions represents an objective view of the exterior details concerning society, culture, or history, impacting the reader's perception of these issues. The reader's perspective is manipulated by what the omniscient narrator reveals. The narrator builds a coherent role as the addresser; the reader is the addressee, thereby moving the narrative from a position of certainty, a narrative mode that contradicts postmodern narration in the authors' attempt to liberate readers by enhancing their independence. By providing the reader with a broad perception of specialized knowledge about the world through an authorial voice, the text becomes the most satisfactory way to communicate with reality. Second, the use of the omniscient narrator allows for multiple individualized perceptions of truth since the author can control the amount of information the reader receives or recognizes about a character, which thus helps represent his/her subjective perception as truthful.

Another primary narrative method associated with the post-postmodernist narrative is metafiction, a technique which is also characteristic of postmodern literature. However, unlike postmodernist metafiction, which "self-consciously and systematically draws attention to its status as an artefact... [and] explore[s] the possible fictionality of the world outside the literary fictional text," the post-postmodern metafiction focus on a pragmatic rather than ontological ${ }^{5}$ framework (Waugh, as cited in Bennett \& Royle, 1995, p.170). As such, post-postmodernist writers' use of metafiction

"no longer seeks to expose and deconstruct fiction's underlying premises. It does not subvert notions of truth and reality in the narrative (...) Instead, it reconstructs fiction as precarious communication and focuses on the ways in which we draw on fictions to make sense of ourselves, our past, our present, and our future" (Huper, as cited in BOYNE'S, 2017, pp. 27-28).

Choosing textual evidence that is either familiar or relevant to literary contexts has an immediate, practical effect on reality, limiting the readers' and characters' uncertainty of their realities, and

Arab World English Journal for Translation \& Literary Studies 
thus focusing on the reconstruction of humanist and ethical aims, such as truthful, meaningful communication.

Franzen's metafictional style in The Corrections and Freedom significantly contributes to this effort, as they includes elements of metafiction and intertextuality, which is considered a metafictional aspect that manifests the existence of "realities" outside of the text (Nikolajeva \& Scott, 2001, p. 227). These elements represent reality within the text (i.e., the way a character makes sense of their reality) and outside of it (i.e., the reader draws connections between the fictional narrative and their reality). The structure of The Corrections and Freedom illustrates the deployment of omniscient narration as a post-postmodern tool, as both novels present the characters from multiple perspectives, and within a fluctuating time frame. The Corrections, for example, opens with a sketch of Enid and Alfred's life from Enid's viewpoint. Then, the second chapter illustrates Alfred and Chips' perspectives in a new setting, while the third part presents the two characters from a myriad of other characters' perspectives. The novel ends with "The Corrections" chapter, which demonstrates some of the characters' resolutions. Freedom has a somewhat, similar, though chronological and more straightforward structure. The novel begins with the presentation of the Berglund family from the external perspective of the neighbors. The family's representation is then followed by an autobiographical account of Patty's life. Subsequently, the rest of the novel is told from the perspective of three characters, Richard, Joey, and Walter.

As representations of the "Maximalist" novel, a new genre in contemporary American fiction that also gained popularity in Europe, Franzen's use of the omniscient narrator in these two texts is significant. The term "Maximalist" narrative was introduced by Ercolino (2014) to characterize works that possess "a very strong morphological and symbolic identity" and are defined by the co-presence of ten elements: "length, encyclopedic mode, dissonant chorality, diegetic exuberance, completeness, narratorial omniscience, paranoid imagination, intersemiocity, ethical commitment, and hybrid realism" (pp. xiii-xiv). These elements are not consistently present in the same form for every text, but they are crucial for defining a maximalist narrative, which provides broad social and cultural critiques. The omniscient narrator is necessary for a maximalist novel because it allows for a holistic view. This mode controls the narrative's materials, representing reality through the interplay of "macrostructural and the microstructural levels" (Ercolino, 2014, p. 100). ${ }^{6}$

The authorial mode of narration in The Corrections and Freedom demonstrates different levels of maximalist narration. These texts represent stories that concern an individual's subject and perspective by providing "a totalizing representation of reality" that manifests a maximalist aspect (Ercolino, 2014, p. 100). The most significant depiction of reality in these texts is evident in the broad descriptions of the American economy, which provides a broader scope of this period's society, culture, and history. By representing these aspects of reality, the real world functions as a setting for the characters' growth and development to engage the reader in understanding the characters. For instance, the omniscient narration of The Corrections mirrors the movements of financial markets and the collapse of Eastern Europe, like in Chip's story about Lithuania:

Arab World English Journal for Translation \& Literary Studies 
Chip was struck by the broad similarities between black-market Lithuania and free-market America. In both countries, wealth was concentrated in the hands of few; any meaningful distinction between private and public sectors had disappeared; captains of commerce lived in a ceaseless anxiety that drove them to expand their empires ruthlessly; ordinary criticizes lived in ceaseless fear of being fired and ceaseless confusion about which powerful private interest owned which formerly public institution on any given day; and the economy was fueled largely by the elite's insatiable demand for luxury. (Franzen, 2001, p. 574)

The novel also provides a list of the Lithuanian institutions' tactics to tempt American investors, like including "the investor's likeness on commemorative stamps" and a range of other materials to show the "extremeness" of American culture, like its "hedonism and empty materialism" (Franzen, 2001; Mulder, 2012). Franzen's representation of America's economic problems and the impact on its society/culture engages the reader because this knowledge already exists in their reallife surroundings, which gives the reader a fuller sense of the characters' choices and motives.

In Freedom, Franzen uses the omniscient mode of narration to expand the novel's politicaleconomic dimensions. For example, Franzen presents these influences through the characters, like Joey, who is "feeling guilty" and Walter, who sees the news segment of "National Public Radio" as "worse" because it is "another voice of center-right-free-market ideology" (Franzen, 2010, pp. $520 ; 423)$.

Joey's military supply business with the American Army and Walter's projects that oppose overpopulation and the free-market are detailed illustrations of the country's political and economic status.

In both novels, Franzen demonstrates omniscient knowledge through the use of metaphors or allegories. In The Corrections, this authorial consciousness is evident through the the recurring metaphor of "corrections," which links family members' dynamic natures with the communal health industry and global market (Dawson, 2013). This metaphor is evident in the depiction of Gary's depression, which makes him believe that "his entire life was set up as a correction of his father's life" (Franzen, 2001, p. 181). One instance of this metaphor is evident in Gary's obsession with correcting his father's mistakes by embracing American capitalism. Another instance comes in his constant reassurance to others that he does not suffer from depression: "Depressed? He was not depressed. Vital signs of the American economy streamed numerically across his manywindowed television screen" (p. 292). Franzen's use of the "corrections" metaphor to criticize materialist, capitalist culture is also evident in Chip's connection with his health problems and consumerism: "The structure of the entire culture is flawed" (Franzen, 2001, p. 43). He dramatically and frequently embraces Foucauldian cultural thinking. Chip adopts Foucault's perspective of discipline and punishment, elaborating a situation's capacity for improvement or punishment (Carroll, 2013). Chip demonstrates the corrective metaphor when he explains that psychological problems are culturally constructed: "the very definition of mental 'health' is the ability to participate in the consumer economy" (Franzen, 2001, p. 44). Thus, through Chip's embracing of the Foucauldian perspective, Franzen shows how late capitalism's culture is "an all-

Arab World English Journal for Translation \& Literary Studies 
encompassing episteme," a system in which individuals cannot be healthy if they do not ascribe to its beliefs, values, and practices. (Carroll, 2013, p. 111).

In Freedom, however, knowledge of the omniscient narrator is reflected in Walter's symbolic view of the environmentalist project that stands in opposition to society's liberal principles. Walter presents many scenarios of the planet's overpopulation while planning financial schemes to save a non-endangered songbird because he believes American society's fate relies on it. Walter thinks that his society's obsession with freedom, as a model for happiness, for in his view, does not appeal to the common good of individuals. He explains to his neighbor, Linda, who wants to teach her children "to take care of a pet and have responsibility," that it is not "a fair fight" to let nonnative cats kill songbirds (Franzen, 2010, p. 727). Ironically, his defense implies that "there is a kind of happiness in the unhappiness" (p. 603).

It can thus be argued that omniscient narration is an essential tool for the construction of "maximalist fiction" (Dawson, 2013, p. 156). At one level, the authorial narration establishes the author's knowledge about current social problems and fulfills his desire to report these issues. Modern globalization widens the post-postmodern individual's understanding of the world's economic and scientific situations. Therefore, the narrator must be well-informed of international issues because they reflect the individual's version of knowledge production and consumption. Post-postmodern authors analyze their contemporary culture by employing the omniscient narrator to contribute to solving the individual's difficulties from a position of certainty, helping him understand his society and culture with a high level of confidence (Dawson, 2013). In other words, the omniscient voice presents a novelist's political and social engagement with human experiences, which makes their arguments and critiques more convincing. On another level, authorial narration projects characters' various perspectives by presenting the inner, subjective perspectives of single fictional characters as truthful. In post-postmodernist narratives, different perspectives of the same account are present throughout the text and are equally valuable. The element of reliability in omniscient narration makes each character's narrative trustworthy and equally important to the other characters' views. So, multiple perspectives are given equal attention by the omniscient narrator, who allots fair opportunities for the characters to deliver their personal accounts while being less influenced by an authorial "hierarchy" that differentiates them (Potgieter, 2012). In Freedom, for instance, the neighbors' external perspective traces the Berglund family's decline which begins when Joey moves next door with his girlfriend. The narrative then shifts to Patty's autobiographical perspective, thorough which she reveals her guilt over her affair with Richard, and links it to the family's dysfunctionality. All views are adequate and maintain the possibility of being right. Different analyses of an event are present in a set of discourses told behind the thread of a single story to deliver a variety of views that constitute meaningful patterns of equally important subjective realities.

In Freedom, the "autobiographer" allows for a deeper reflection on the aesthetics of reality and trust in the narration style (Franzen, 2010). Every aspect of Patty's life is retold from the autobiographer's perspective, with multiple comments expressing regret or providing explanations that enhance her self-esteem. Even though the autobiographer and Patty represent the same person, the former has a different voice to describe past events, which compels Patty to trust this voice 
over herself. The meaning of each detail about Patty's life changes when it is recounted "in an irony then invisible to Patty but now plenty visible to the autobiographer" (p. 187). Patty's autobiographical writing embodies truth because it presents her experiences as they occur, so they are without personal reflections. Olney (1980) writes, "an autobiography shares experience as its way of revealing reality" (p. 55). So, this omniscient style reflects a deep authenticity, as it articulates a narrative that represents realities:

The autobiographer, mindful of her reader and the loss he suffered, and mindful that a certain kind of voice would do well to fall silent in the face of life's increasing somberness, has been trying very hard to write these pages in first and second person. But she seems doomed, alas, as a writer, to be one of those jocks who refer to themselves in third person. Although she believes herself to be genuinely changed, and doing infinitely better than in the old days, and therefore worthy of a fresh hearing, she still can't bring herself to let go of a voice she found when she had nothing else to hold on to, even if it means that her reader throws this document straight into his old Macalester College wastebasket. (Franzen, 2010, p. 83)

Post-postmodernist writers use metafictional devices in their novels not to distance the reader from reality. Instead, they are used as modes of self-expression to enhance the understanding of the characters (Potgieter, 2012). In postmodernist literature, the primary effect of metafictional techniques is to reflect literary playfulness and explicitly expose fiction's conventions. Still, the post-postmodernists argue: "[t]he only metafictional device that has utility for critiquing metafiction itself is metafiction's own propensity toward self-theorization" (Little, 2004, p. 74). Therefore, they attempt to write an "anti-metafictional metafiction" (p. 14).

Many post-postmodernist critics reject the irony of metafiction, moving beyond skepticism towards authenticity (Funk, Groß \& Huber, 2012). According to Wallace, metafictional elements are employed in the post-postmodern narrative "to expose the illusions of metafiction the same way metafiction had tried to expose the illusions of the pseudo unmediated realist fiction that came before it" (as cited in Conversation with David, 2012, p. 40). Burn (2008) stresses the metafictional aspects' effects within the closed systems of the post-postmodernist novels and explains that contemporary writings rely on conventions of realism. Even though they embrace a level of ontology while inserting certain metafictional elements, one "hopes to draw the reader's attention outside the book" to unfold different ways to construct life's stories (p. 127). Franzen follows the post-postmodernist critique of metafictional devices and uses them to expose reality rather than the illusory. The Corrections and Freedom illustrate several intertextual dialogues with fictional texts or the inclusion of genuine people and historical events, which are all narrativized to develop a realistic sense within and outside the text.

A significant metafictional aspect in The Corrections is Franzen's use of intertextual dialogue with William Gaddis' work, The Recognitions. Chip's email address, “exprof@gaddisfly.com," which he uses to report to his job in Lithuania (Franzen, 2001, p. 559). Burn (2008) explains that the title of Franzen's novel also has a symbolic allusion to Gaddis's The Recognitions based on its desire to analyze those who are unable to "distinguish the false from the 
authentic" (p. 98). According to Burn, Chip resembles Gaddis' character, Otto Pivner, a moneyobsessed writer whose observation that "a man does feel castrated in New York without money," recalls the moment when Chip complains, "without money he was hardly a man" (p. 98). Franzen even admits that his novel pays homage to Gaddis' first novel regarding its quest for the real:

The novel is like a huge landscape painting of modern New York... a quest for authenticity in a phony modern world. Improvising on the theme of art forgery, Gaddis fills his novel with every conceivable variety of fraud, counterfeiter, poseur, and liar (...) the main characters of 'The Recognitions' participate in the phoniness themselves. The young literary poseur, Otto Pivner, is working on a play whose plot, he says, 'still needs a little tightening up'. (Franzen, 2002, p. 7)

Chip's failure to complete his screenplay translates Franzen's description of the "literature of emergency," that "[t]he moderns employed" using "new, self-conscious methods to address the new reality and preserve the vanishing old one" (p. 11), a type of literature that Chip finally comprehends as he realizes ability to enact a "correction" to "be a man with dignity in this world," thus proving Franzen's argument that "[f]iction is storytelling, and our reality arguably consists of the stories we tell about ourselves" (Franzen, 2001, p. 141; Franzen, 2002, p. 12).

Freedom includes an intertextual reference to Tolstoy's War and Peace, which has two effects. First, Patty reads this work due to Walter's suggestion, ironically reflecting the love triangle between Patty, Walter, and Richard to Tolstoy's characters: Natasha, Andrei, and Pierre. Patty links the feelings of these characters to her real story: "Patty felt she'd lived an entire compressed lifetime in those three days, and when her Pierre returned from the wilderness, badly sunburned despite religious slatherings of maximum-strength sunblock, she was ready to try to love him again" (Franzen, 2001, p. 239). In this way, she allows a fictional subject to serve as a realistic model rather than perceiving it as a preoccupation with the unreal. These intertextual references provide the narrative with a realist framework since the novel's historical account mirrors the nineteen-century writers' concern with realism. History and materiality are two primary themes of the nineteenth-century realist narrative (Hidalga, 2017). Franzen's novel is set in a military-industry complex during the American invasion of Iraq. It references the epochal conflicts of the Napoleonic Wars in Tolstoy's novel, echoing the novel's realist account. Franzen's intertextual dialogues represent the post-postmodern tendency to expand the story's pragmatical dimension by stressing real-world elements beyond the text.

Franzen's writing process not only consists of signifiers that refer to fictional narratives and describing relationships between literary books, but he also refers to real discourses, reflecting layers of realism. In Freedom, to bridge the gap between the text and reality, Franzen discusses the event of 9/11. Franzen depiction of the lasting impact of this real-life trauma on one of his characters, Joey, who escapes during the event transforms his work from the fictional level into the richer, more complex realm of the real (Franzen, 2010). Another example of metafiction is the author's inclusion of real people, like Bill Clinton, which reveals a second layer of realism. For Patty, Clinton is a figure that "is no way intended to exculpate her but simply to elucidate her state of mind" (p. 201). By referencing real-life events and characters, Franzen deliberately blurs the 
lines between fiction and reality. By so doing, he enhances the reader's perception of reality, allowing him to develop a sense of familiarity with the fictional world, and to assimilate the fictional world with the authenticity of his lived experiences.

\section{Conclusion}

The new changes in novels' style and characterization have not been outlined in a detailed ground since the 1990s. The long-term embrace of the hyper real than the real throughout the postmodern age has come to an end with the emergence of authors like Jonathan Franzen who contributed in a movement that hopes to reconnect the human to his real existence. Therefore, as As Franzen's The Corrections and Freedom mirror, contemporary writing withdraws from the postmodern mode of disconnection and adheres to a style and language of engagement, a preoccupation with feelings, thoughts, and experiences concerning a period's changes. This approach describes the post-postmodern movement, necessitating various transformations and redeployments of the postmodern delineation of identity and the definition of narrative tools. To explore the realistic tendencies in Franzen's novels, this study approaches subjectivity as a productive, pragmatist discourse that helps reconstruct the post-postmodern character. The ideal post-postmodern identity in Franzen's two novels is less concerned with how it is identified or recognized by others; it never changes based on social or political influence, but achieves selfcontrol and self-recognition, by engaging with its transcendent realities beyond the scope of irony and skepticism.

The study reveals the renewal of the omniscient narrator in The Corrections and Freedom, which entails specific platforms that may alter the postmodern view of ending representations. As an effective conduit of faithful representation, omniscient narration is employed in contemporary fiction to report an all-knowing analysis of social and cultural structures. The maximalist and experimental voice of post-postmodern narration, which passes broad, superior judgment on the fictional world, has an overriding effect on the reader's understanding of reality. In a variation of this trend, Franzen theorizes about a renewal of trust and reality in literature while critiquing social and ethical ills by utilizing omniscient narration to illustrate a preoccupation with societal and cultural progress.

By analyzing the two novels, The Corrections and Freedom, this study evinces how Franzen, as a post-postmodernist, offers a new version of realism by narrating new ways of remedying the contemporary individual's existential crisis through the return to the aesthetics of trust. Both novels demonstrate Franzen's efforts to enforce the notions of reality and trust through the use of intertextuality and metafiction as means that distinguish his works from postmodernist writings. His metafictional style constructs an exchange between consciousnesses (i.e., a character's and reader's understanding of the world) to allow needs to be freshly perceived. The aspects of metafiction do not disturb the characters' realities but demonstrate how Franzen draws connections are based on realistic (rather than illusory) grounds. The reframing of metafictional elements in post-postmodernist fiction expands this movement beyond the development of deep layers of realism. It challenges the relationships between irony and sincerity, evident in Wallace's fiction. The Corrections and Freedom, Franzen demonstrates how post-postmodern fiction utilizes the postmodern approach to reconnect humanity with various capitalist, ecological, and socio- 
cultural systems, which caused humanistic shortcomings. Rather than criticizing the world, Franzen's post-postmodernist fiction provides solutions to the individual's problems, by assuming new corrective directions that acknowledges truth and reality beyond the confining boundaries of the text.

\section{Endnotes}

1. This refers to the unsustainable population under a capitalist system (Gram, 2014).

2. "The term globalization refers not to a stable, defined reality, but a complex debate about social, political, and economic processes in the contemporary period" (Annesley, 2006, p. 113).

3. This refers to the actions needed to buttress the individual's identity (Hidalgo, 2017).

4. Yousef (2017) explains that this is "concerned with the nature of being" (p. 37).

5. The maximalist novel's "macrostructural" structure stands for "the narrative as a whole," or the entire narrative flow, while its "microstructural" level refers to a "single fragment" story within the text (Ercolino, 2014, pp. 99-100).

\section{About the Authors:}

Mashael H. Aljadaani is a lecturer at the English Language Institute at Umm Al-Qura University, Saudi Arabia. She received her MA in English Literature from King Abdul-Aziz University. Her research interests include postmodern literature and gender studies. "The Subversion of Gender Stereotypes in Donald Barthelme's Snow White"' is an example of her research.ORCID ID: https://orcid.org/0000-0003-4252-3013

Laila Mohammed Al-Sharqi is an associate professor of English in the Department of European Languages and Literature at King Abdul-Aziz University, Saudi Arabia. She received her Ph.D. in literary theory and cultural studies from the University of Nottingham. Her research interests include postmodern literature, literary theory, gender studies. "Magical realism as a feminist discourse in Raja Alem's Fatma" and "Twitter Fiction: A new creative literary landscape" are examples of her research.ORCID ID: https://orcid.org/0000-0001-8142-1525

\section{References}

"Jonathan Franzen Takes the Long Road To 'Freedom': The Couple At The Story's Center" (2010). NPR: All Things Considered. Retrieved from https://www.npr.org/templates/story/story.php?storyId=129799680

Annesley, J. (2006). Market corrections: Jonathan Franzen and the" novel of globalization". Journal of Modern Literature, 29(2), 111-128. DOI: $\underline{10.1353 / \mathrm{jml} .2006 .0015}$

Bamberg, M. (2011). Freedom, narrative, and happiness. Journal of Family Theory \& Review, Hoboken, 3(4), 320-325. DOI:10.1111/j.1756-2589.2011.00109.x 
AWEJ for Translation \& Literary Studies Volume, 5 Number 1. February 2021

The Evolution of Post-Postmodernism: Aesthetics of Reality

Aljadaani \& Al-Sharqi

Baudrillard, J. (1994). Simulacra and simulation. Ann Arbor . University of Michigan press.

Bennett, A., Royle, N., \& Watson, K. (1994). Elizabeth Bowen and the Dissolution of the Novel: Still Lives. New York. Springer.

BOYNE'S, I. J. (2017). Post-Postmodernist Humanism, Young Adult Literature And The Holocaust, Ghent, Ghent University.

Brown, C. (2012). Practical judgment in international political theory: selected essays. Milton Park, Routledge.

Burn, S. J. (2008). Jonathan Franzen at the end of postmodernism. Bloomsbury Publishing.

Carroll, J. (2013). Correcting for the corrections: A Darwinian critique of a Foucauldian novel. Style, 47(1), 87-118.

Chris Abani: Global Igbo (2015). YouTube, uploaded by Chicago Humanities Festival. 13 Nov. Available at Nov. www.youtube.com/watch?v=mofJiqcrzr8.

Dawson, P. (2013). The Return of the Omniscient Narrator: Authorship and Authority in TwentyFirst Century Fiction. Columbus, Ohio State University Press. Retrieved from https://kb.osu.edu/bitstream/handle/1811/58524/Dawson_Book4CD.pdf?sequence=1

DeFalco, A. (2010). Uncanny Subjects: Aging in Contemporary Narrative. Ohio State University Press. Available at www.academia.edu/11373462/Uncanny_Subjects_Aging_in_Contemporary_Narrative.

Derrida, J. (2007). Structure, Sign, and Play in the Discourse of the Human Sciences." 1967 (Trans. R. Macksey, \& E, Donato). In D. H. Richter (ed.), The Critical Tradition: Classic Texts and Contemporary Trends ( $3^{\text {rd }}$ ed., pp. 915-26). Boston: St. Martin's.

Dubey, M. (2011). Post-postmodern realism?. Twentieth Century Literature, 57(3/4), 364-371. Ercolino, S. (2014). The Maximalist Novel: From Thomas Pynchon's Gravity's Rainbow to Roberto Bolaño's 2666. Bloomsbury Publishing, USA.

Finkelstein, J. (2007). The Art of Self Invention: Image and Identity in Popular Visual Culture. Bloomsbury Academic.

Franzen, J. (2002) How to be Alone: Essays. New York. Picador.

Franzen, J. (2001). The Corrections. Farrar, Straus, Giroux. New York.

Franzen, J. (2002). Mr. Difficult: William Gaddis and the problem of hard-to-read books. The New Yorker, 30, 100-11.

Franzen, J. (2010). Freedom. Library of Congress Cataloging. New York.

Funk, W., Groß, F., \& Huber, I. (Eds.). (2014). The aesthetics of authenticity: medial constructions of the real. Transaction Publishers.

Gram, M. H. (2014). Freedom's Limits: Jonathan Franzen, the Realist Novel, and the Problem of Growth. American Literary History, 26(2), 295-316.

Hall, D. E. (2004). Subjectivity: The New Critical Idiom. Routledge.

Hartness, P. B. (2009). Po Pomo: The Post Postmodern Condition, (Unpublished Master's thesis). Washington, Georgetown University, . Available at

Arab World English Journal for Translation \& Literary Studies 
AWEJ for Translation \& Literary Studies Volume, 5 Number 1. February 2021

www.repository.library.georgetown.edu/bitstream/handle/10822/552837/hartnessPaula.pdf ?sequence $=1 \&$ is Allowed $=\mathrm{y}$.

Hassan, I., Rudrum, D., \& Stavris, N. (2015). Beyond Postmodernism: Toward an Aesthetic of Trust. Supplanting the Postmodern: An Anthology of Writings on the Arts and Culture of the Early 21 st Century, 15-29. DOI 10.5040/9781501306907.ch-002

Hendry, M., \& Page, J. (Eds.). (2013). Media, technology, and the imagination. Cambridge Scholars Publishing.

Hidalga, J. B. (2017). Jonathan Franzen and the Romance of Community: Narratives of Salvation. Bloomsbury Publishing, USA.

Hosseini, S., Pirnajmuddin, H., \& Abbasi, P. (2018). Jonathan Franzen's The Corrections:

Ethics of Complexity. Journal of Language Studies, 18(4), (186-200), Available from http://doi.org/10.17576/gema-2018-1804-12.

Koubová, A. (2013). Self-identity and Powerlessness. Leiden. Brill.

Little, M. R. (2004). Novel affirmations: defending literary culture in the fiction of David Foster Wallace, Jonathan Franzen, and Richard Powers, (Unpublished Doctoral Dissertation) Texas, Texas A\&M University.

Lynch, R. A. (2012). The art of governing: the critical ethics of Michel Foucault, (Unpublished Doctoral dissertation). Chestnut Hill, Boston College. Retrieved from https://dlib.bc.edu/islandora/object/bc-ir\%3A101282/datastream/PDF/view.

Millard, K. (2007). Coming of age in contemporary American fiction. Edinburgh University Press.

Mulder, S. (2012). The Striking Sustainability of Literary Realism, (Unpublished Master's Thesis). Available at www.dspace.library.uu.nl/handle/1874/252906.

Nealon, J. T. (2012). Post-Postmodernism: Or, the Cultural Logic of Just-in-Time Capitalism. Stanford University Press.

Nikolajeva, M., \& Scott, C. (2001). How Picturebooks Work. Garland Publishing.

Olney, J. (Ed.). (1980). Autobiography: Essays, Theoretical and Critical. Princeton University Press.

Potgieter, S. (2012). Post-postmodernism in Contemporary American Fiction: An Analysis of Jonathan Franzen's Freedom and Jennifer Egan's A Visit from the Goon Squad, (Unpublished Bachelor Thesis). Netherlands, University of Utrecht, .

Foucault, M. (1997). Ethics: Subjectivity and Truth,(ed) Paul Rabinow. London: Allen Lane.

Smith, R. (2005). Prologue. After Postmodernism: Education, Politics, and Identity, edited by Smith, Richard, and Philip Wexler. E-book, Taylor \& Francis.

Solomon, R. C. (2001). From rationalism to existentialism: The existentialists and their nineteenth-century backgrounds. Rowman \& Littlefield.

Swann Jr., W. B. (2012). Self-verification theory. In P. Van Lang, A. Kruglanski, \& E.T. Higgins (Eds.). Handbook of theories of social psychology (pp. 23-42). London: Sage Publications Ltd. 
AWEJ for Translation \& Literary Studies Volume, 5 Number 1. February 2021

Tanenhaus, S. (2010). Peace and War" review of Freedom by Jonathan Franzen. New York Times.

Timmer, N. (2010). Do you feel it too?: The post-postmodern syndrome in American fiction at the turn of the millennium (Vol. 44). Amsterdam, Rodopi.

Van Katwyk, P. (2009). Constructed identity, subjective identity and inter-subjective transformation: An exploration by way of motherhood and Canadian maternity benefits, (Unpublished Doctoral dissertation). Waterloo, Wilfrid Laurier University, Retrieved from https://scholars. wlu.ca/cgi/viewcontent.cgi?article $=2080 \&$ context=etd.

Wallace, D. F. (2012). Conversations with David Foster Wallace. University Press of Mississippi.

Walonen, M. K. (2016). Contemporary World Narrative Fiction and the Spaces of Neoliberalism. Macmillan Publishers.

Weinstein, P. (2015). Jonathan Franzen: The Comedy of Rage. Bloomsbury Publishing, USA. Yousef, T. (2017). Modernism, postmodernism, and metamodernism: A critique. International Journal of Language and Literature, 5(1), 33-43. DOI: 10.15640/ijll.v5n1a5 